\title{
A ESTRUTURA PÓS-COLONIAL DE “QUARUP”, DE CALLADO
}

Licia Soares de Souza ${ }^{1}$

Resumo: Este trabalho analisa Quarup (1967) de Antonio Callado. Considerado um romance de êxodo reverso, segundo o modelo narrativo explorado por Euclides da Cunha, cujos viajantes partem da metrópole para averiguar os modos de existência do Brasil profundo, nos sertões ou nas reservas indígenas, Quarup é classificado como um romance de tese. Correlacionando várias correntes de pensamento, em ondas dialéticas de tese e antítese (getulismo, comunismo, indigenismo, folclorismo, sertanismo, europeísmo, cubanismo, etc.), Callado desenvolve uma narrativa apta a mostrar as tendências ideológicas que guiavam as comunidades nos conturbados anos do início da ditadura militar. Pretendemos mostrar que esse tipo de romance de tese, cujo entrelaçamento de correntes de pensamento diferenciados surge espelhando os impasses causados pela adoção de ideologias importadas, com caracteres colonialistas, muitas vezes, constitui 0 embrião do romance pós-colonial que politiza o estético no Brasil.

Palavras-chave: Romance pós-colonial, Quarup, Antonio Callado.

Résumé: Ce travail analyse Quarup (1967) d'Antonio Callado. Vu comme un roman d'exode à l'envers, selon le modèle narratif exploré par Euclides da Cunha, dont les voyageurs partent de la métropole pour aller vérifier les modes d'existence du Brésil profond, dans les sertões ou dans les réserves indigènes, Quarup est classé comme un roman à thèse. Ce roman met en relation plusieurs courants de pensée, en ondes dialectiques de thèse et antithèse (getulismo, communisme, indigenisme, folklorisme, sertanismo, européisme, cubanisme, etc.), tout en développant un récit apte à montrer les tendances idéologiques qui guidaient les communautés dans les années troublées du début de la dictature militaire. Nous voulons montrer que ce type de roman à thèse, dont l'enchevêtrement de courants de pensée différenciés miroite les impasses causées par l'adoption d'idéologies importées avec des caractères colonialistes parfois, constitue l'embryon du roman post-colonial qui politise l'esthétique au Brésil.

Mots-Clés: Roman post-colonial, Quarup, Antonio Callado.

Quarup, considerado o livro mais ambicioso de Antonio Callado, publicado um pouco antes do opressivo Al-5, em 1967, se inscreve na categoria do romance realista-político (SILVERM AN, 2000, p. 293). Mas Quarup se inscreve igualmente na linhagem que Silverman batiza de êxodo reverso, périplo que leva os protagonistas a se afastar das megalópoles consumistas e multinacionalizadas do litoral, para se embrenhar pelo interior em busca de um reencontro telúrico. Tal reencontro deve ser destinado a fazer emergir raízes etnográficas e geopolíticas, no Brasil profundo, aptas a redefinir a identidade nacional.

1 Universidade do Estado da Bahia - UNEB. Enreço eletrônico: c1464@er.uqam.ca. 
Esta linha foi inaugurada por Os Sertões (1902), reapresentada por Grandes sertões veredas (1956), e por M aíra (1977), uma década após Quarup.

\section{ROM ANCE de TESE E Pós-COLONIAL}

Em Quarup, o padre Nando, um celibatário tímido e sexualmente frustrado se transforma num revolucionário entusiasta e provocador, no estado de Pernambuco, nordeste do Brasil. Todo o projeto visionário de Nando volta-se efetivamente para o centro do Brasil nesse movimento de êxodo reverso, do litoral para o interior. 0 romance instaura assim uma tese pacifista de um intelectual católico, que se torna um ex-padre sertanista, entrecruzada com visões míticas do país.

Francisco dos Santos (1999), pesquisador do autoritarismo no Brasil, lança-se na interpretação da conjuntura brasileira, através da obra de Callado, que ele classifica como um romance de tese. 0 romance de tese, remontando ao surgimento do romance burguês, nos séculos XVIII e XIX, amenizou sua fórmula durante o século XX. Esta fórmula, baseada no confronto entre um projeto narrativo (tese) e nítidos obstáculos (antítese) sofreu vários processos desconstrutores até gerar romances híbridos do pós-modernismo que desarticulam e re-articulam idéias, valores e utopias bem delineados.

Émile Zola é considerado o exemplo mais significativo de romancista de tese, aquele que concebeu o romance como uma investigação geral sobre a natureza e o homem. M as este criador da forma mais discutida de romance de tese, calcada no método experimental das ciências naturais de Claude Bernard, não excluiu a incerteza metodológica ao dizer que o raciocínio experimental é baseado na dúvida (SANTOS, 1999, p. 22).

Em Zola, a idéia de romance já continha uma abertura para o mundo, para o texto social. Também no naturalismo, o mundo, como é sabido, o universo referencial, é um produto de semiose e não um dado pré-existente. Santos (1999, p. 70-71) prossegue, assim, discutindo sobre o romance de tese, a partir dos estudos de Ronaldo Lima Lins (1990) e Benjamin (1987). A base desses estudos é o caráter dialético do romance que deve articular a instância da narrativa e o domínio da informação. Benjamin temia inclusive que o domínio da informação superasse cada vez mais a narrativa, de tal forma que ressalta a figura do narrador como o grande articulador de experiências de vida. Por outro lado, Lima tem posto a ênfase na história do enredo e suas transformações, a fim de mostrar exatamente como a matéria referencial dos romances vai encontrando fórmulas variadas de arranjo e de organização.

Com as reflexões de Santos, podemos inclusive avançar uma hipótese que nossas análises poderão corroborar ou não. 0 romance de tese brasileiro pode ser 0 embrião do romance pós-colonialista no país? Existem romances de 134

A Cor das Letras - UEFS, n. 9, 2008 
tese emblemáticos. 0 missionário de Inglês de Sousa aparece em um contexto cultural em que liberais e maçons apresentam uma mentalidade semelhante a seus adversários, os católicos identificados com o Império, em relação ao progresso civilizatório da burguesia agrária. O lluminismo brasileiro, do final do século XIX, evolui nas crises do dilema civilização x atraso (barbárie) que continua a desafiar o país até hoje: "M issão católica e razão liberal unem-se com vistas à conquista de índios para o mundo do progresso" (SANTOS, 1999, p. 75).

Tem-se Canaã, de Graça Aranha, escrito numa fase em que os intelectuais estavam desencantados com a República. Sua temática toca em terror cósmico, na problemática das raças e na constituição de uma metafísica brasileira, "indício de proposta inovadora devido a sua atitude antipasssadista" (SANTOS, 1999, p. 75).

Em seguida, surge Quarup, numa época em que a cultura de esquerda tem hegemonia, mas encontra-se perplexa e desencantada pela perda das esperanças de renovação do país, pela chegada do governo militar autoritário. Santos mostra que Callado dá forma às teses que inquietavam a intelectualidade brasileira em sua experiência histórica; tais como os messianismos cristão e libertário, os projetos de modernização do país, o indigenismo e 0 ethos desenvolvimentista. 0 percurso existencial do padre Nando, sertanista, ativista político e guerrilheiro, com seus projetos utópicos, desdobra-se ao longo do romance com suas modificações. Sua tese utópica inicial propõe a repetição do modelo da República "Comunista" Cristã dos Guaranis entre os índios Xingu. M as essa utopia vai implodindo diante da realidade, pois se acha calcada numa visão etnocentrista baseada nos argumentos da culpa e do destino manipulado por uma entidade transcendente.

Além dessa utopia guarani, vários outros códigos se entrecruzam para formar a rede simbólica que permite os confrontos téticos e antitéticos dos variados sistemas de idéias e de valores. 0 getulismo aparece como uma ideologia das massas em mobilidade. Aponta para as formações ideológicas ligadas à política trabalhista do Estado Novo e à doutrina da paz social. A política do trabalho necessita de uma semiótica (SANTOS, 1999, p. 174), um sistema de representação, estruturado com símbolos determinados, para equilibrar as tensões entre os trabalhadores e os patrões industriais.

A trama romanesca põe igualmente em cena os projetos de interiorização do desenvolvimento com a conseqüente colocação em prática de uma política indigenista de defesa do índio. As dialéticas do desenvolvimentismo se entrecruzam e fazem brotar problemas específicos dos anos 1950 e 1960, as- 
sim como questões relativas aos impasses crônicos do atraso x modernização ${ }^{2}$ (SANTOS, 1999, p. 207).

A trama se instala em um período de dez anos, mais precisamente de 1954 a 1964, no qual várias utopias libertárias se interrelacionam. 0 nacionalismo esteticista, o sertanismo e o indigenismo buscam a alma do nativo do Brasil profundo com o objetivo de livrar o país de invasões alienígenas. Com estas utopias se desenrola a concepção da raça cósmica. Como é um período de organização ideológica do país, se imbricam várias ideologias de luta - 0 trotskismo, o jaguncismo messiânico, o jaguncismo guerrilheiro - através das quais se desdobram concepções de revolução sem violência, de revolução armada ou de revolução pelo cubanismo.

Nessa perspectiva, a obra se caracteriza como um verdadeiro romance de tese, à medida que todos esses sistemas de idéias se entrelaçam em rede, um servindo de antítese para o outro. A síntese advinda desses confrontos, um argumentário simbólico, possui um extraordinário poder transformador, uma vitalidade inesgotável porque é uma atividade inacabada implicando diálogo.

Santos (1999, p. 286) afirma que a tradição do romance de tese no Brasil privilegia o confronto de espíritos messiânicos. Inglês de Sousa, por exemplo, mistura ingredientes contraditórios como o catolicismo, o mundanismo, o esteticismo e o ódio ao provincianismo medíocre. Ora, essa experiência estética, que ficcionaliza um país inacabado e contraditório, imbuído de um projeto iluminista de edificação de uma civilização branca no litoral, desemboca no projeto estético do pós-colonialismo.

A narrativa de Callado confere existência, com coerência expressiva e semântica às teses sonhadas pelos intelectuais, em suas diferenças, com raízes na cultura heterogênea do país, através do percurso cognitivo do padre Nando, que é evidentemente um signo -veículo de várias teses e antíteses. M as o desdobrar narrativo não fixa nenhuma síntese, dissolvendo os conceitos antitéticos de natureza e cultura, ao mostrar os embates entre brancos e índios, guerrilheiros e militares, litorâneos e sertanejos.

A desconstrução das ideologias messiânicas e libertárias nos traz, assim, para o campo do pós-colonialismo. 0 procedimento pós-colonial existe na medida em que se movimenta no sentido de apontar antíteses para os sistemas simbólicos de pensamento com pretensões gerais e universais. Relativizando a história e a visada geográfica das representações, este novo romance póscolonial, derivado do romance de tese, politiza a estética mostrando as contradições advindas das incorporações de sistemas simbólicos importados e a

2 Como as contradições autoritarismo x democracia, ênfase na produção econômica x ausência de ética e o enigma do subdesenvolvimento. 
sua fragmentação diante do real empírico. É como se os objetos de representação das formações discursivas das utopias literárias entrassem em curtocircuito com os signos representados.

Em outras palavras, o romance pós-colonial põe em cena os dilemas entre pensamento e realidade, questionando a legitimidade da aceitação de determinados sistemas de valores mundializados pelo eixo euro-norte-americano nos ditos países de periferia global. É o caso, por exemplo, do trotskismo aplicado à realidade camponesa brasileira, ou mesmo das utopias guerrilheiras face às ideologias dos militares as quais são também importadas dos Estados Unidos, em plena Guerra Fria.

É assim que esse tipo de romance, que materializa os dilemas do uso de sistemas simbólicos mundiais, que se caracteriza como de tese e que evolui para uma espécie de acrobacia estética, de caráter icônico, pronta a desarticular os núcleos duros de seus símbolos, se torna pós-colonial.

\section{OVIMENTOS DE UMA NARRATIVA DE TESE}

Para começarmos a visualizar a estrutura narrativa de Quarup, podemos lançar mão de uma análise estrutural do discurso narrativo proposta por Roland Barthes (1973, apud SOUZA, 2006). Para começar, tem-se a Seqüência que é uma série lógica de Funções, ligadas por uma relação de solidariedade: os termos se pressupõem uns aos outros. A estruturação de Funções em Seqüências e destas, entre si, forma a Sintaxe funcional. Toda Seqüência recebe uma denominação, de livre escolha do analista, mas intimamente ligada à lógica que a estrutura, podendo ser expressa por um nome ou por um infinito verbal cognato. Uma Seqüência é uma unidade e, como tal, pode servir de termo a outra maior.

Vejamos a estrutura de Quarup. 


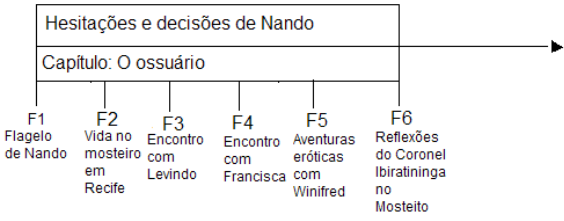

S2

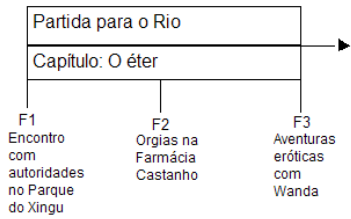

S4

\begin{tabular}{|c|c|c|c|c|c|c|c|c|c|}
\hline \multicolumn{5}{|c|}{ Peregrinações no Xingu } & & \multicolumn{4}{|c|}{ Expedição ao centro geográfico } \\
\hline \multicolumn{4}{|c|}{ Capitulo: A maça } & & & \multicolumn{3}{|c|}{ Capitulo: A orquídea } & \\
\hline $\begin{array}{l}\text { F1 } \\
\text { Chegada } \\
\text { de } \\
\text { Nando: A } \\
\text { maçã. }\end{array}$ & $\begin{array}{l}\text { F2 } \\
\text { Revelação } \\
\text { do projeto } \\
\text { Getulista }\end{array}$ & $\begin{array}{l}\text { F3 } \\
\text { Preparo } \\
\text { do Quarup } \\
\text { indigena }\end{array}$ & $\begin{array}{l}\quad \text { F4 } \\
\text { Sônia } \\
\text { foge com } \\
\text { Anita }\end{array}$ & $\begin{array}{c}\text { F5 } \\
\text { Realização } \\
\text { do Quarup }\end{array}$ & $\begin{array}{l}\quad \text { F1 } \\
\text { Marcha para o } \\
\text { oeste, rumo } \\
\text { ao indios } \\
\text { Txukassamae }\end{array}$ & $\begin{array}{l}\text { F2 } \\
\text { Marcha ao } \\
\text { encontro } \\
\text { dos Cren }\end{array}$ & $\begin{array}{l}\text { F3 } \\
\text { Ramiro } \\
\text { busca } \\
\text { Sônia }\end{array}$ & $\begin{array}{l}\text { F4 } \\
\text { Chega } \\
\text { da ao } \\
\text { Centro }\end{array}$ & $\begin{array}{l}\text { F5 } \\
\text { Morte de } \\
\text { Fontana }\end{array}$ \\
\hline
\end{tabular}

S5

S6

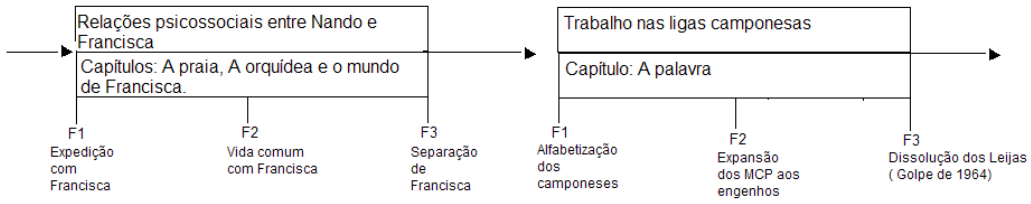

S7

S8

\begin{tabular}{|c|c|c|c|c|c|c|}
\hline \multicolumn{3}{|c|}{ Detenção de Nando } & \multicolumn{4}{|c|}{ Quarup para Levindo } \\
\hline \multicolumn{2}{|c|}{ Capitulo: A palavra } & & \multicolumn{3}{|c|}{ Capitulo: A praia } & \\
\hline $\begin{array}{c}\mathrm{F} 1 \\
\text { Inquérito }\end{array}$ & $\begin{array}{c}\mathrm{I} \\
\mathrm{F} 2 \\
\text { Tortura }\end{array}$ & $\begin{array}{l}\text { F3 } \\
\text { Libertação: Diálogo } \\
\text { com o coronel } \\
\text { lbiratininga. }\end{array}$ & $\begin{array}{l}\text { F1 } \\
\text { Preparação } \\
\text { da festa }\end{array}$ & $\begin{array}{l}\text { F3 } \\
\text { Realização } \\
\text { da festa }\end{array}$ & $\begin{array}{l}\text { F4 } \\
\text { Chegada dos } \\
\text { Soldados: } \\
\text { Surra em } \\
\text { Nando }\end{array}$ & $\begin{array}{c}\text { F5 } \\
\text { Libertação } \\
\text { de Nando. }\end{array}$ \\
\hline
\end{tabular}

56

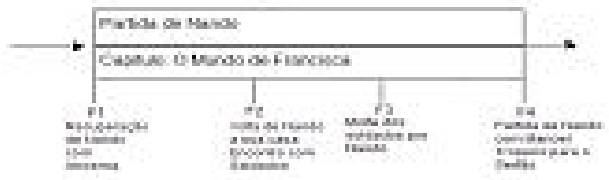


Em primeiro lugar, observemos que cada Seqüência não corresponde apenas a um capítulo determinado, e que elas podem articular elementos de vários capítulos.

A S1 é denominada Hesitações e decisões de Nando e ela se encontra no primeiro capítulo 0 Ossuário. A narrativa tem início com o padre Nando no Mosteiro, em Recife, em 1954, assustado pela idéia de partir para a missão com os índios no Xingu, e praticando sessões de auto-flagelo. Seu superior D. Anselmo já havia Ihe concedido a permissão para travar relações com gente do mundo. Antes de partir, Nando se relaciona com Levindo, jovem revolucionário trotskista, conversando muito com sua noiva Francisca também (a qual pretende ir ao Xingu captar o inconsciente dos índios por meio de desenhos corporais que contariam a história das tribos), e se relaciona com os brasilianistas ingleses Leslie e sua mulher W inifred com quem ele tem relações sexuais.

Nando é uma espécie de guia turístico do Monastério e assessor de D. Anselmo. Discute muito com Hosana, padre sacrílego que vive de carência de fé e de desrespeito ao celibato clerical, mas que cuida dele (Nando) após as sessões de tortura pelo governo militar, dez anos mais tarde, em 1964. As blasfêmias de Hosana falam da transferência da fé católica da Europa para a América, através da imagem do Deus decomposto que veio em porão, como os escravos. Justamente, esse Deus europeu já não é um signo puro, mas um signo sincretizado com os dos deuses africanos.

É importante notar, nessa S1, as discussões do major do exército Ibiratinga com os frades (que não atendem seus desejos) acerca de suas convicções políticas. 0 major, que aprecia as ações da Santa Inquisição e que admira 0 nazismo, torna-se um personagem chave na ascensão do governo militar no Brasil e na prisão e tortura de Nando em 1964. Nessa época (1954), ele faz pressões sobre D. Anselmo para poder violar o confessionário, obtendo nomes e endereços de pessoas simpáticas ao demônio do comunismo.

Após esse capítulo de hesitações, Nando vai para o Rio, e é no capítulo 0 Éter que a forma de vida da megalópole Rio de Janeiro é delineada, na confluência de vários sistemas de idéias. Como capital federal, o Rio abriga as sedes das instituições e é lá que Nando vai encontrar o ministro Gouveia da Agricultura e o diretor do Serviço de Proteção aos Índios (SPI), Ramiro Castanho, para preparar sua viagem para o Xingu.

Ramiro Castanho aparece como um signo-veículo determinado de teses eurocentristas: Era gordo, pálido, bigodinho negro cuidadosamente aparado e mãos manicuradas (Q, p. 101). Para Santos (1999, p. 160), a visão de Ramiro, que nasceu no Catete e só conhece São Paulo, além do Rio, coincide com o ponto de vista da elite que dirige o Estado nacional, sem conhecimento prático 
da vida do povo e dos grupos étnicos do país. Encarregado do setor que se ocupa da política dos índios, nutre desdém por eles: Eu aceitei esse abacaxi dos índios por amizade ao M inistro Gouveia (Q, p.91), e trata-os de bugre e de porcos fedorentos. Nando vive um carnaval em companhia de Ramiro e penetra no mundo da droga, da lança-perfume e do éter.

Como signo-veículo, Ramiro indica uma formação de tese e outra de antítese. É um mazombo ${ }^{3}$ contemporâneo (SANTOS, 1999, p. 104) que nutre fascínio pela cultura francesa (como parte da intelectualidade brasileira até a primeira metade do século XX), vivendo simbolicamente do outro lado do Atlântico, mais especificamente em Paris. 0 médico Ramiro defende a mentalidade francesa em oposição à cultura norte-americana. Partidário do etnocentrismo, o personagem é favorável à continuidade da herança européia francesa e latina que poderia mudar os rumos do país. Adota um discurso de dimensão surrealista (SANTOS, 1999, p. 171), misturando palavras estranhas, conceitos e trocadilhos: "[...] esta joça brasileira, ainda que mergulhe o nariz num oceano de éter, jamais se desjoçará", "descholdrizasse", "deu- se a melodia".

Ramiro defende a tese do eurocentrismo, mas desconstrói as teorias do caráter nacional brasileiro de M iguel Pereira e Paulo Prado (Retrato do Brasil), em relação às teses étnicas e psicológicas de que existem traços hipocondríacos na cultura brasileira: A coisa é a seguinte. Há no Brasil uma vocação para a doença. 0 Brasil é um grande hospital. A tal frase do Miguel Pereira ficou, (Q, p. 128). Ramiro ridiculariza a sociologia de Miguel Pereira e a tese de Paulo Prado que afirma que o Brasil é um caso único de vocação para a doença. Parodiando esses discursos, o proprietário da Farmácia Castanho satiriza a indústria da doença, pretendendo escrever um ensaio crítico do sistema economicista brasileiro que contempla a doença como instrumento de dinâmica econômica e a busca de solução como um bom motor de movimento de rendas.

A S3, Peregrinações no Xingu, se desenvolve no capítulo A maçã que tem esse título por causa da cena da chegada de Nando ao alto do Xingu.

\footnotetext{
Seu primeiro casal de índios. Nus. Ela apenas com seu uluri, ele apenas com um fio de miçangas na cintura. Deram dois passos para fora da casa. Voltaram-se um para o outro, Nando, que estacara, viu então que a mulher tinha na mão direita uma maçã, que oferecia ao companheiro. 0 índio fez que não com a cabeça. Ela mordeu a maçã. E então, virando-se para Nando, foi lentamente andando em sua direção, a maçã na mão estendida em oferta. Nando, confuso, pôs a mala no chão, estirou a mão.

Uma risada estourou atrás de Nando, outra ao seu lado, e das malocas saíram em chusma índios rindo e gritando, homens e mulheres e crianças (Q, p. 153).
}

3 Nome dado aos filhos de portugueses nascidos no Brasil até o início do século XVIII. 140 A Cor das Letras - UEFS, n. 9, 2008 
A peça pregada pelos sertanistas do SPI tem o sentido metafórico de lembrar ao padre o cenário do pecado original com a mordida da maçã por Eva, nessa paródia do relato bíblico. Nesse sentido, ele se introduz em um paraíso de pecado permitido.

Mas nessa Seqüência de preparo do quarup ${ }^{4}$, a F2 tem um papel preponderante no desenrolar da trama, pois o presidente Vargas é esperado para a cerimônia indígena. Como o diz Santos (1999, p. 174), as verbalizações do varguismo ou getulismo prometem melhoria das condições de vida dos humildes, a realização da democracia econômica e social e proteção para o trabaIhador. Essa projetada viagem do presidente do Brasil ao interior, que sertanistas, desbravadores, e representantes da burocracia estatal desejam, constitui um núcleo argumental vital para se debater a política federal em relação ao destino dos indígenas e à interiorização do desenvolvimento.

Otávio, o representante do Partido Comunista Brasileiro, avalia a visita como uma solução momentânea para os problemas que vivem os indígenas, isolados no Centro do país. Nesse caso, a obra de Callado oferece uma visão crítica da crise que se instaura no campo com a política de atração de trabaIhadores para o espaço urbano, estabelecendo outro duelo argumental entre 0 discurso populista do varguismo e sua antítese desdobrada na vida sacrificada dos indígenas. Esta antítese ganha um clímax significativo no momento em que se anuncia o suicídio de Vargas em pleno quarup, para o desespero dos sertanistas. Sem a presença do presidente, vão-se as esperanças de melhoria das condições de vida para os índios.

Nessa mesma Seqüência, tem-se a F3 e a F4 que se referem ao preparo e à realização do quarup. Para Santos (1999, p. 188) as cenas romanescas do quarup mostram uma impossibilidade de síntese e apontam para a descaracterização do mito indígena. No quarup, Yawalapit, é o indigenista Fontoura que funciona como yayat (diretor da festa) em lugar de Canato, o verdadeiro morerekwat (capitão) da tribo. No universo do sagrado, são introduzidos elementos profanos pelos brancos na direção do cerimonial. Por outro lado, Fontoura põe pessoas não xinguanas no ritual da pesca coletiva, uma cerimônia destinada a

4 o quarup é uma cerimônia religiosa intertribal de celebração dos mortos, ligada ao ciclo mitológico de um herói cultural, conhecido entre os camaiurás como Mavotsinin, que acontece no Parque indígena do Xingu, entre os povos indígenas brasileiros da região do alto Xingu (MT). Essa cerimônia é relacionada com a celebração de finados. No entanto, o quarup é uma festa alegre em que cada um põe sua melhor roupa. Troncos feitos da madeira chamada "kuarup" representam os espíritos dos mortos ilustres que estão sendo festejado e relembrados. Sob a ótica dos índios, os mortos querem ver os vivos alegres, bonitos. 
garantir a abundância durante a celebração do mito das origens. Os brancos introduzem, por outro lado, instrumentos estranhos ao ritual como a bomba, para aumentar os produtos da pesca, em lugar do timbó, o que não deixa de impressionar os índios.

Mas o que é interessante é que o ponto de vista de Nando passa a ser assumido pelo narrador que conta o mito focalizando o processo cognitivo do padre que vai avaliando as cenas que contempla com comentários acerca dos mitos das tribos do Xingu. Muita ironia marca igualmente o relato do cerimonial indígena que, longe de exprimir um diálogo entre civilização e autoctonia, aponta antes para o antagonismo das culturas. Na preparação do quarup, temse outro motivo chave para a diegese do romance que é a chegada da personagem Sônia, noiva do jornalista Falua, e desejada por Ramiro, que abandona o mundo dos brancos, para fugir com o índio Anta. Sônia é a motivação para Ramiro acompanhar a expedição ao Centro Geográfico do país (em S4), instaurando uma semiótica da ruptura e da perda na qual a união do branco e do índio só pode acontecer se os dois desaparecerem da área de empiria das duas culturas.

A S4 trata justamente de uma temática da expedição e aborda a totalidade do chamado êxodo reverso. 0 motivo da expedição parece servir de pano de fundo para "relacionar presente e passado como tempo ficcional e por 0 relato nos planos do real e do imaginário, afastando a tentação da leitura exclusivamente documental e histórica" (SANTOS, 1999, p. 218). Quarup divulga aqui a tese indigenista ${ }^{5}$.

Os sertanistas Fontoura, Vilaverde e Nando (que passa a ser um indigenista) adentram na selva, como verdadeiros discípulos de Rondon. Situam-se contra a degradação dos índios sobreviventes em contacto com a civilização dos brancos. Os expedicionários encontram os suiá, partem em busca dos txukanamãe, também índios não pacificados, e, finalmente, se deparam com os cren-acárore, considerados um terror para as demais tribos porque falava-se que eles teriam se apoderado das terras planas.

Com a dificuldade de comunicação, os expedicionários procuram investigar se os cren eram realmente os monstros que se apoderaram das terras, com ou sem guerra. Mas tiram suas conclusões, após encontrá-los moribun-

5 Santos (1999, p. 218) mostra que Quarup se inscreve na categoria de romance indigenista. 0 indigenismo se distingue do indianismo, à medida que aí o índio é o personagem central e orienta uma temática que valoriza sua cultura. 0 indianismo tinha uma visão romântica do índio que funciona como personagem acessório diante do processo civilizatório dos brancos. 0 índio aí fala como um português e age segundo os valores de seus colonizadores. 0 maior representante o indianismo é Alencar. A obra de Callado e de Darcy Ribeiro é indigenista. Vide igualmente Silvina Carrizo (2005). 
dos, famintos e incapazes de caça e pesca, mostrando que os ditos selvagens não possuem nenhuma possibilidade de resistir à civilização branca. Como 0 indigenista Fontoura morre durante a expedição, a posição indigenista em Quarup se mostra novamente dialética, indicando as fragilidades dos dois lados, do indígena e do branco. Os conceitos antitéticos de civilização e barbárie, mais uma vez, resistem a uma síntese simbólica, permanecendo em estado icônico-indicial, no qual suas semelhanças e diferenças se confrontam sem aceder a um estado de síntese explicativa, que, segundo muitos pesquisadores, seria o núcleo gerador da cultura brasileira.

$\mathrm{Na}$ confluência dos códigos que atravessam a Expedição, é preciso notar o nacionalismo esteticista que se encarna em Lauro, um grande especialista em lendas brasileiras.A ironia que cerca a atuação desse personagem é que ele possui um conhecimento enciclopédico sobre lendas e mitos, mas desconhece o espaço nacional, sentindo mesmo angústia e medo durante a expedição. Antes da expedição, Lauro evoca a figura do jabuti como a figura por excelência de um verdadeiro autóctone que deve recusar a anta prepotente, "imensa e forte" que pode representar a figura do gringo usurpador.

A S5 aborda as relações de Nando e Francisca, através de três capítulos. 0 protagonista de Quarup, após ter passado por um processo gradativo de desconstrução simbólica, revisitando valores e idéias, entra em nova dialética no campo do amor. Tornando-se mestre na arte de amar, propõe utopias eróticas, com o pensamento de libertação dos sentimentos de arroubos possessivos. Sua semiologia erótica é vivida, em plenitude, com Francisca, noiva de Levindo, que morre na luta, e que é posta em analogia com a terra brasileira. Esta é dividida entre o mar e o sertão, abrindo novo caminho dialético e nova impossibilidade de síntese, quando Nando opta por se evadir no sertão amplo e solitário, correndo dos militares. Francisca permanece um signo ligado às imagens da praia, unindo água e terra numa dinâmica de fusão.

A seqüência S6 orienta a construção da utopia democrática que se desenvolve com as Ligas camponesas, no governo de M iguel Arraes, em Pernambuco. Após o desencanto da utopia xinguana, o ex-padre Nando pensa em investir na revolução sem violência, pelo viés da "conscientização" e da "reforma" dos meios de produção. Ele enfrenta a oposição (construindo uma antítese a sua nova tese utopista) de Januário, revolucionário cubanista e dos trotskistas que acreditavam que a pedagogia deveria engendrar uma revolução com tomada de poder através de violência. Neste contexto, os messianismos vão se confrontando igualmente com os embates entre o comunismo secular e os ideais cristãos de outros padres evangelistas e milenaristas. 
No desenrolar da S6, o argumento de expansão dos MCP - Movimento de Cultura Popular- aos engenhos se acentua em descrições significativas sobre a construção de palavras ligadas ao cotidiano das pessoas. É a colocação em prática romanesca do método Paulo Freire que estipula o re-inventar e resignificar das palavras em suas situações de comunicação. Não é à toa que 0 capítulo se intitula A Palavra, no qual o efeito de iconicidade do processo ensino-aprendizagem, no meio camponês, provoca efeitos de real em situação de opressão.

- Eu re - disse um camponês.

- Eu remo-disse outro.

- Eu clamo- disse outro.

- Eu sei professora, eu sei Dona Francisca. Eu reclamo!.

M esmo agora, já habituado a assistir e a ensinar ele próprio, Nando sentia os oIhos cheios d'água, quando diante de um camponês uma coisa ou uma ação virava palavra. A criança tantas vezes vai fazer a coisa a comando da palavra. Para aqueles camponeses tudo já existia menos a palavra.

- De - disse um camponês.

- Cla - disseram todos.

- Ra - disse um camponês.

- Declaração - disse outro (Q, p. 384).

Esse trabalho de construção indicial da palavra ligada a saberes partilhados significa exatamente a busca dos meios expressivos para um sistema de valores que existia sem contexto representante apto a lhe dar existência nas comunidades. Constituição, Declaração, Lei Áurea, Direitos do Homem, Nações Unidas, escravidão, República, Frevo, Bumba-meu-boi, eram signos componentes de códigos sócio-políticos e culturais que iam se incorporando na vida dos camponeses. Mas o golpe militar de 1964 subverte o poder democrático e implode as utopias libertárias e democráticas dos M CP.

Neste mesmo capítulo, A Palavra, se desenrola a S7: Detenção de Nando. Vejamos um trecho de diálogo de Nando com o Coronel Ibiratinga, no momento em que o detento é libertado.

- Então - disse, o coronel - o que eu quis dizer é que me cansei de alertar D. Anselmo contra o demônio. Porque eu tenho uma tese sobre o Brasil, a mais séria que já se propôs sobre o Brasil. E a estou agora desenvolvendo em livro, depois de havê-la exposto aos pedaços - mas pedaços vivos e sangrentos - à Escola Superior de Guerra, ao próprio D. Anselmo, a todos que me pareciam dignos de ouvi-la.

- Será o Jabuti? pensou Nando, enquanto o Coronel Ibiratinga prosseguia.

- Falta uma cinza de virtude em nossos campos, é o título do capítulo inicial do meu tratado. Nunca tivemos esse adubo. Nunca queimamos hereges e infiéis, nunca matamos aqueles que insultam as coisas sagradas. No fim do primeiro século tivemos a grande oportunidade de criar na alma do Brasil o arcabouço de 
ferro da alma dos grandes países. 0 senhor deve conhecer bastante bem a história das duas visitações que fez o Santo Ofício ao Brasil, entre 1591 e 1595 (Q, p. 452).

O revolucionário pacifista Nando se dá conta, neste diálogo, que a violência institucionalizada é o código das novas forças que governam o país. 0 personagem, até então pacifista, permanece estupefato diante do militar que defende um salvacionismo de extinção que é homólogo ao de Hitler: "Ibiratinga encampa as teses do uso da força contra os inimigos na ocupação do espaço e da energia no exercício do poder" (SANTOS, 1999, p. 264).

A S8 trata do jantar Quarup que Nando resolve fazer para festejar a morte de Levindo. A comilança deve assinalar a continuidade da luta, reunindo líderes que já passaram pela tortura e que não foram para o exílio. Para Nando, é um rito de passagem de sua utopia pacifista a sua utopia antitética significada pela luta armada. É também o momento de aceitação da liderança jagunça de Manoel Tropeiro que iconiza o sertanejo guerreiro e guerrilheiro de linhagem euclidiana com quem Nando parte para o sertão a fim de se livrar dos militares.

Como o quarup indígena é a abundância alimentar, a comilança nacional, com sua natureza antropofágica, se desdobra em uma iconicidade estética, assinalando fartura.

O inventário de peixes, pescados, pimentas, doces, azeites, camarões, refrescos,
licores e outras iguarias compõe um dos delineamentos do retrato do Brasil, rico
e heterogêneo, e se harmoniza, com o quarup, que conforme já mostramos, tra-
ta-se de festa ritual.
De outro foco de análise, a proveniência e as especialidades das cozinheiras (bai-
ana, alagoana, maranhense, amazonense), mulatas, negras e brancas represen-
tam o processo civilizatório brasileiro, caracterizado pela mestiçagem. Por últi-
mo, os convidados presentes: jangadeiros, líderes de sindicatos rurais,
representantes de várias etnias, em sua quantidade, estabelece uma homologia
com a festa indígena, além de retratar, no plano da ficção, a diversidade do país
(SANTOS, 1999, p. 282).

M as um novo embate antitético se instaura no momento em que a $\mathrm{M}$ archa da Família, com ares de desfile militar, entra em conflito com os convidados do jantar para Levindo, assassinado pelas forças do poder. Nando é agredido pelos soldados e se encontra mutilado com o olho esquerdo estropiado e uma perna ferida. É recuperado por Hosana e seus amigos e, finalmente, ao voltar a sua casa, mata, junto com M anoel Tropeiro, os soldados que o espreitavam (S9). Com sua deseducação completa, o herói de Quarup toma o rumo do sertão, com o jagunço militante Manoel Tropeiro, como se adentrasse no território sagrado do interior do Brasil que livrava guerreiros guerrilheiros das 
milícias federais. Mas, como diz Silverman (2000, p. 297), 0 ato final de Nando tem sucesso apenas simbólico, pois, na verdade, ele já estava condenado: como estiveram condenados Antonio Conselheiro e Lamarca.

Vendo o desenrolar dessas 9 Seqüências com todas as suas funções primordiais, de significância na diegese, o que fica patente é justamente que Callado empreende um esforço de codificar a realidade brasileira, através de seus vários sistemas de pensamento que se mesclam nessa década histórica de 1954 a 1964. Cada sistema evidentemente forma um código de valores que se cruza na rede ideológica da época que põe em cena os embates que indicam as formações téticas com suas correspondentes formações antitéticas. 0 romance de tese engendra assim um romance pós-colonial que reúne em sua forma a dialética de várias visões de mundo que se encontram em uma plataforma relacional, sob o signo da dinâmica da tese/antítese, para desconstruir ideologias prontas que vão sendo reterritorializadas lá onde elas se desestruturam diante de uma existência singular.

\section{PalaVRas finais: a Poutização do Estético no Pós-COLONial}

Efetivamente, descolonizar, para a canadense Diana Brydon (apud SANTOS, 2005, p. 31), não é simplesmente livrar-se das amarras do poder imperial, é procurar também alternativas não repressivas ao discurso imperialista Dessa forma, os textos pós-coloniais contra-escrevem as ficções imperialistas e assim as leituras pós-coloniais podem direcionar a atenção para as diferenças culturais e produções locais de resistência. É como se o pós-colonial pudesse se alinhar com o movimento de mundialização permitindo ao pós-modernismo de se circunstanciar em relação a sociedades determinadas, relativizando a história e a visada geográfica das representações. E Santos (2005) mostra que a força da teoria pós-colonial pode estar na sua capacidade comparativa e em sua metodologia híbrida de visão de mundo, livrando-se de passados que supervalorizam a ancestralidade e o puro em detrimento da visão sincrética dos hibridismos.

Os estudos pós-coloniais tornam-se assim particularmente fecundos para reconfigurar os limites problemáticos entre centro e periferia, globalização e mundialização, literatura e uma multiplicidade de vertentes culturais que circulam na contemporaneidade, como faz Callado com Quarup. Passagem do universal aos múltiplos particulares, a idéia do pós-colonial compreende, desde então, conotações complexas que se destinam a mostrar a força política dos imperialismos. 0 pós-colonial não se limita apenas a estetizar o político, ele politiza o estético, diz Brydon, e exprime uma escritura da resistência capaz de revelar as condições das lutas entre dominantes e dominados. 
Mas quando se considera que o pós-colonial não pode ser interpretado apenas pelos epistemas europeus do pós-estruturalismo e do pósmodernismo, parte-se pra buscar outros modos de consideração das formas de enfrentamentos entre, pelo menos, duas culturas, uma dominando a outra. A cultura considerada como dominada desenvolve frequentemente mecanismos de mestiçagem ${ }^{6}$ e de hibridismo ${ }^{7}$, os mais produtivos possíveis, aptos a modelizar os elementos monosêmicos de cada cultura a fim de deixar aflorar as estruturas de transcodagem ativas que podem permitir os sincretismos necessários (lembremos da mestiçagem cultural baiana, do sincretismo religioso, que funde ativamente elementos da cultura portuguesa e africana). Um sistema modelisante híbrido neste sentido constrói um sistema referencial que não reflete simplesmente as raízes de uma cultura bem organizada na sua linearidade temporal e coerência espacial, mas uma atividade discursiva que põe em cena suas próprias condições de articulação de elementos distintos. Este sistema modelisante pós-colonial é uma organização de discursos como produção de discursos. E, nesta dinâmica, podemos ver que a obra de Callado já se impunha como uma das melhores ilustrações do pensamento pós-colonial bem antes dele se afirmar como tal.

\section{REFERÊNCIAS}

CALLADO, Antonio. Quarup. 12. ed. Rio de Janeiro, Nova Fronteira, 1984. [1964].

CARRIZO, Silvina. Indigenismo. In: FIGUEIREDO, Eurídice. (Org.). Conceitos de literatura e cultura. Rio de Janeiro, EDJF/EDUFF, 2005, p. 207-224.

COSER, Stelamaris. Híbrido, hibridismo e hibridação. In: FIGUEIREDO, Eurídice. (Org.). Conceitos de literatura e cultura. Rio de Janeiro, EDJF/EDUFF, 2005, p. 163-188.

SANTOS, Eloína P. Pós-colonialismo e pós-colonialidade. In: FIGUEIREDO, Eurídice. (Org.). Conceitos de literatura e cultura. Rio de Janeiro, EDJ F/EDUFF, 2005, p. 341-366.

SANTOS, Eloína P.; FIGUEIREDO, Eurídice. (Org.). Intertextualidade pós-moderna: uma estratégia de descolonização. Recortes transculturais. Niterói, EDUFF/ABECAN, 1997, p. 47-64.

SANTOS, Francisco V. Callado no lugar das idéias. Quarup um romance de tese. Rio de Janeiro, Caetés, 1999.

SILVERM AN, Malcolm. Protesto e o novo romance brasileiro. 2. ed. Rio de Janeiro, Civ. Brasileira, 2000.

SOUZA, Licia Soares de. Introdução às teorias semióticas. Petrópolis, Vozes, 2006.

SOUZA, Licia Soares de. A influência centenária de uma fundação: Os Sertões como a grande narrativa histórica do Brasil. Revista da ANPOLL, n. 16, p. 147-182, jan/jun 2004.

6 Vide histórico do conceito em Silvina Carrizo (2005).

7 Vide Stelamaris Coser (2005). 
